\title{
OCCURRENCE AND INTENSITY OF SPINAL PAIN IN MOTORCYCLISTS DEPENDING ON MOTORCYCLE TYPE
}

\author{
Roksana Wójcik, ${ }^{\text {A, B, C, D Bartosz Trybulec }}{ }^{\text {A,B, D }}$ \\ Jagiellonian University Medical College, Faculty of Health Sciences, Graduate at faculty of Physiotherapy, Cracow, Poland

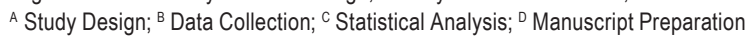 \\ Address for correspondence: \\ Bartosz Trybulec \\ Zakład Fizjoterapii WNZ UJ CM \\ Badurskiego 19 \\ 30-694 Kraków, Poland \\ E-mail:bartosz.trybulec@uj.edu.pl
}

\begin{abstract}
Ahstract Introduction: Motorcycles in Poland become more and more popular also as convenient means of transport, especially in large cities. Factors influencing on driver during riding the motorcycle are assumed to cause spinal pain in motorcyclist. These factors may vary in motorcycles of different construction or purpose. Few information is available about spinal pain connected with riding a motorcycle. The aim of this study was the assessment of occurrence and intensity of spinal pain in motorcyclists depending on motorcycle type.

Material and methods: The study group consisted of 2,124 motorcyclists aged 19-79 yrs., using motorcycle with an engine size bigger than $50 \mathrm{ccm}$ and participating in minimum 1 riding season. An original, on-line available questionnaire composed of questions regarding riding a motorcycle and ailments of all parts of the spine was used. The results underwent statistical analysis using the Statistica 10.0 .

Results: The results showed that $58.4 \%$ respondents experienced pain of at least one part of spine during riding the motorcycle. The biggest percentage $(51.1 \%)$ of persons with spinal pain in general was found out in cross/enduro type users. Neck pain was significantly connected with riding the sport motorcycle $(p=0.001)$.

Conclusions: Spinal pain in motorcyclists depends on the motorcycle type.
\end{abstract}

Key Worlds back pain, motorcyclists, motorcycle type, drivers

\section{Introduction}

Spine pain is one of the most frequent disorders occurring in general population. Epidemiological studies show that lifetime prevalence of low back pain (LBP) concerns even $84 \%$ of population (Balagué, Mannion, Pellisé, Cedraschi, 2012). Neck pain occurs in about $23.1 \%$ of general population, which places it on the second place after LBP while women are more susceptible than men (Hoy, Protani, Buchbinder, 2010). The factors determining occurrence of spinal pain are, among others, long time maintained static position, whole body vibrations (WBV) and awkward sitting positions. These factors may also appear during riding the motorcycle (Goode, Carey, Jordan, 2013; 
Sasin, Cieślak, 2014; Bovenzi 2010). Simultaneously, motorcycles become more and more popular mean of transport in Poland and number of issued driving licenses systematically increases. The license of A category was acquired by 13,240 in the year of 2013 and 12,557 in the year of 2014. Generally in Poland this category of driving license is possessed by 4.8 million people whereas the number of registered motorcycles also increased by $18 \%$ in relation to previous year and the number of motorcycles with engine size up to $125 \mathrm{ccm}$ increased by $40 \%$ due to the possibility of driving with "B" license only (GUS, 2014).

Depending on construction features and operational characteristics the following types of motorcycles can be distinguished: sport, tourist, cruiser/chopper, enduro/cross. About the selection of motorcycle most often decides its purpose without regarding the matching up to the individual physiological and anatomical limitations of the driver. Different construction determines significantly different positions taken on particular types of motorcycles. Sports motorcycles have many features adapting them to riding on sport tracks e.g. plastic fairings improving aerodynamics, smaller wheelbase and weight, lower and hard adjusted suspension and relatively higher engine power. Enduro/ cross type motorcycles designed for riding in difficult terrains are usually lighter with solid, strengthened construction of frame and suspension, without fairings but with center of gravity located higher than in other types. Due to recreational or sport purpose this type is commonly one-seated. Tourist motorcycles designed to covering long distances are longer and heavier than sport or cross/enduro machines, with more ergonomic position and additional

a)

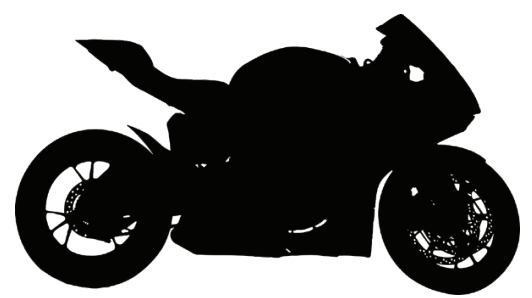

c)

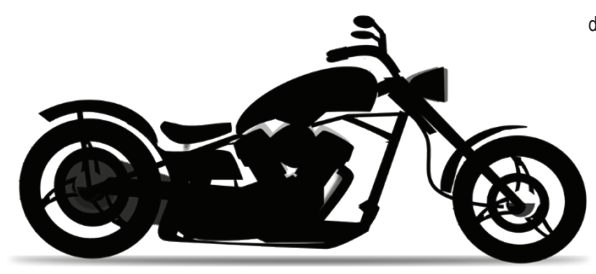

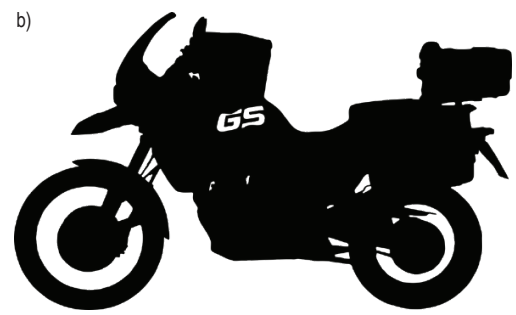

d)

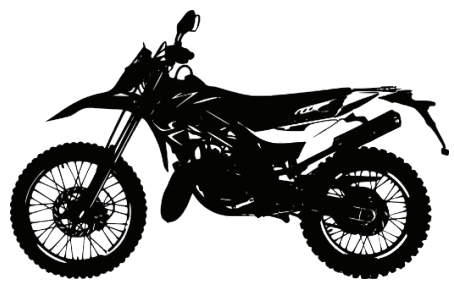

e)

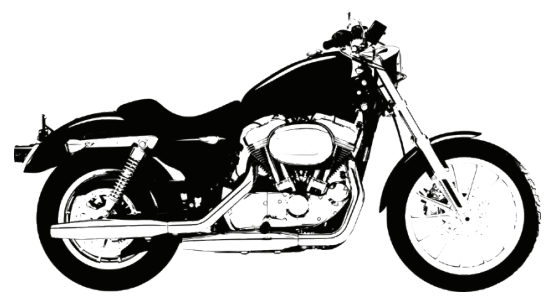

Figure 1. Examples of particular motorcycle type outlines: a) sport, b) tourist, c) chopper, d) enduro/cross, e) cruiser Source: www.pixabay.com (8.02.2017). 
frames for luggage or cases. Cruiser and chopper are both low seated types with extended handle bars while chopper type is differentiated by strongly forwarded fork and raised, T-shaped handle bars (Figure 1a-e) (Teoh, Campbell, 2010).

Various types of motorcycles due to lack of possibility of adjustment determine constant specific riding position. Body positions on individual motorcycle type with angle values between particular body parts are shown on figures 2-5 (source: own based on cycle-ergo.com - accessed: 6.01.2017).

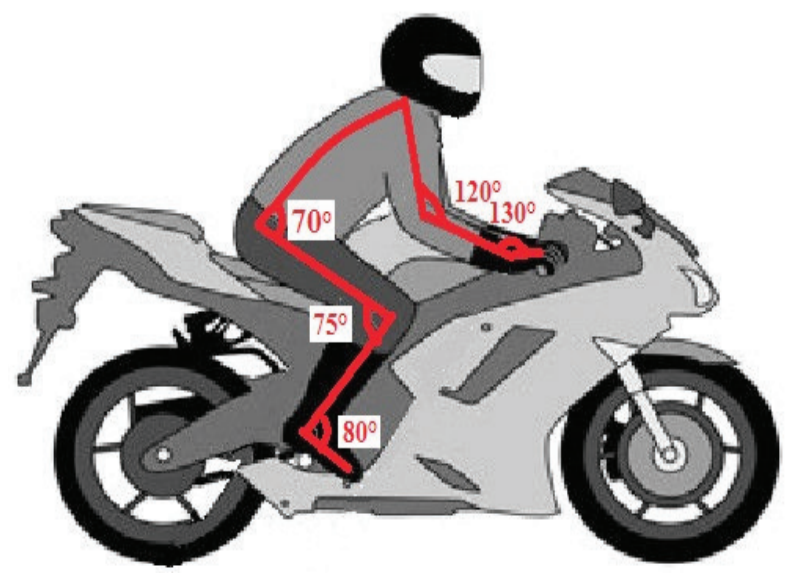

Figure 2. Position on sport motorcycle

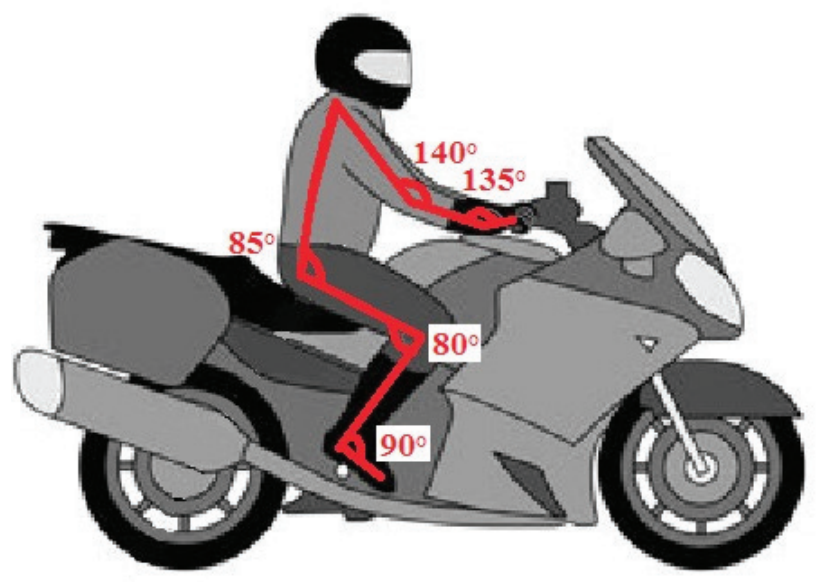

Figure 3. Position on tourist motorcycle 


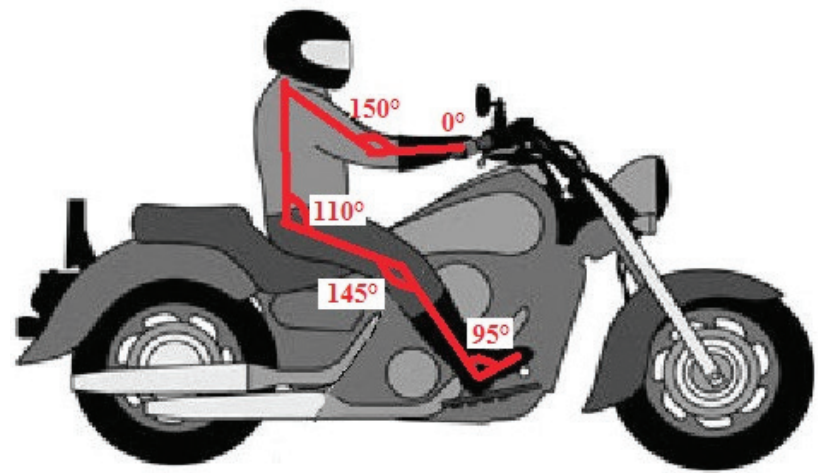

Figure 4. Position on cruiser/chopper motorcycle

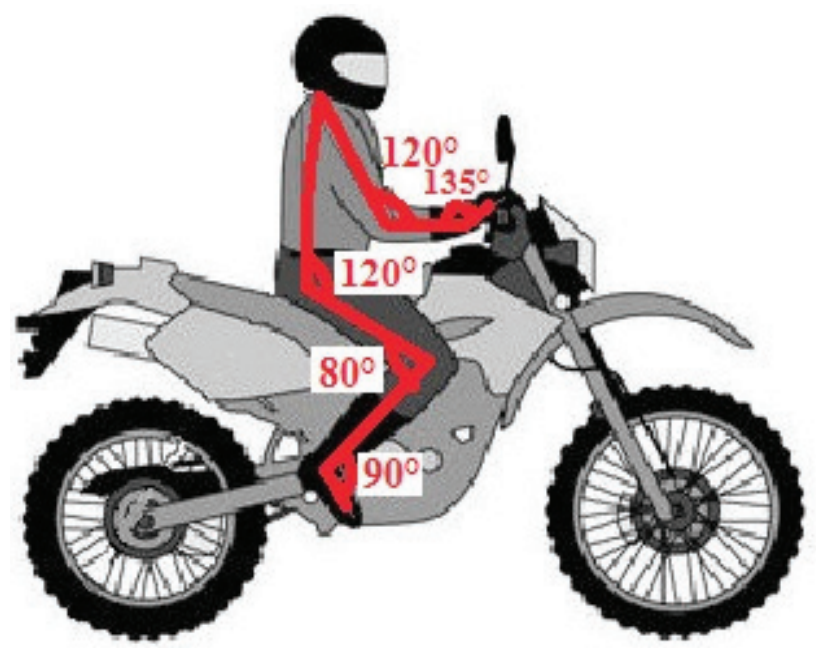

Figure 5. Position on cross/enduro motorcycle

Static position maintained for long time and vibrations transmitted onto the driver are main factors that may cause spinal pain during or after riding the motorcycle. Sitting longer than 20 minutes leads to decrease of muscle tension which causes passive structures (ligaments, joint capsules) to seize the role of stabilizers. Longlasting tension of ligaments may cause its structural disorders thus decreasing elasticity and efficiency. In such situation human body gives pain impulse which is assumed to effect in position change. When it is impossible the ailments can become stronger and pathological changes can occur. Such situation can also take place during riding the motorcycle (Goode et al., 2013). Repetitive long-lasting disorders of muscles and ligaments may cause morphological changes that can be irreversible (Sheeran, Sparkes, Caterson,Busse-Morris, van Deursen, 2012). 
Motorcyclists during riding are also exposed on whole body vibrations that can be generated by the engine and ground bumps and could be transmitted onto the driver because of rigid construction of chassis. They can be divided to local - transmitted from handle bars to hand - and general - transmitted through the seat into the trunk (Bovenzi, 2010; Slatkovska, Alibhai, Beyene, Cheung, 2010).

The goal of this study was the assessment of the occurrence, frequency and intensity of pain in all parts of the spine in motorcyclists in relationship to the type of the motorcycle used.

\section{Material and methods}

\section{Study group characteristics}

We collected 2881 records of persons who meet inclusion criteria. The inclusion criteria were: riding the motorcycle with engine size over $50 \mathrm{~cm}^{3}$, having relevant category of driving license and participation in at least one riding season which was defined as time period from March until October inclusively. Persons, who declared having of formally diagnosed disorders that can proceed with spinal pain were not involved in the study group. The final study group consisted of 2,124 motorcyclists meanly aged $29.7 \mathrm{yrs}$., in that 1,754 (82.6\%) men and 370 (17.4\%) women residing in Poland. Mean of height was $178.4 \mathrm{~cm}$, mean weight was $80.38 \mathrm{~kg}$ and mean BMI was $25.14 \mathrm{~kg} / \mathrm{m}^{2}$ (Table 1).

Table 1. General somatic characteristics of examined persons

\begin{tabular}{lccccc}
\hline Parameter & $\mathrm{n}$ & $\overline{\mathrm{x}}$ & $\mathrm{SD}$ & Minimum & Maximum \\
\hline Age $(\mathrm{yrs})$ & 2,124 & 29.70 & 9.05 & 19 & 79 \\
Weight $(\mathrm{kg})$ & 2,124 & 80.38 & 7.89 & 40 & 140 \\
Height $(\mathrm{cm})$ & 2,124 & 178.40 & 8.03 & 150 & 205 \\
BMl $\left(\mathrm{kg} / \mathrm{m}^{2}\right)$ & 2,124 & 25.14 & 4.02 & 16.2 & 42 \\
\hline
\end{tabular}

Considering the type of motorcycle 737 (43.7\%) persons have sport motorcycle, 711 (33.47\%) tourist motorcycle, cruiser/chopper have 535 (25.19\%) respondents and cross/enduro 141 (6.64\%) of them (Figure 6).

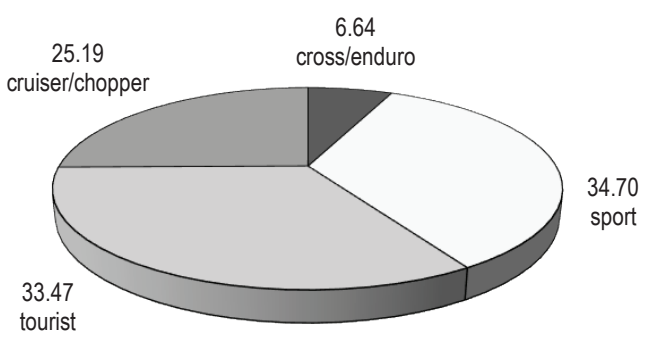

Figure 6 . Percentage of particular motorcycle type in the study group 
Motorcycle was mainly used for tourism by $1,162(67.75 \%)$ of respondents. The least respondents have used it for sport 277 (13.04\%). 697 (32.82\%) of respondents have used the motorcycle 4-times per week while 458 (21.56\%) 2-1 per week and only 18 persons ( $0.85 \%$ ) less often than 1 per month. Average number of riding years was 8.77 while average number of seasons comes to 6.36 . The respondents rode meanly 2.72 hours a day with monthly mileage on average $1,030.78 \mathrm{~km}$ (Table 2). The majority of the respondents $(2,022$ persons $-95.2 \%)$ used specialized protective clothing during riding.

Table 2. Characteristics of selected parameters related to motorcycle riding in the study group

\begin{tabular}{lccccc}
\hline \multicolumn{1}{c}{ Parameter } & $\mathrm{n}$ & $\overline{\mathrm{x}}$ & $\mathrm{SD}$ & Minimum & Maximum \\
\hline Riding years & 2,124 & 8.77 & 8.52 & 1 & 53 \\
Number of seasons & 2,124 & 6.36 & 5.75 & 1 & 53 \\
Riding hours per day & 2,124 & 2.72 & 1.56 & 0.5 & 9 \\
Monthly mileage $(\mathrm{km})$ & 2,124 & $1,030.78$ & 978.59 & 20 & 11,000 \\
\hline
\end{tabular}

\section{Examination}

The research was conducted between January and April 2015 through authors questionnaire available on-line at university platform ankiety.cm-uj.krakow.pl designed with LimeSurvey Manual (ver. 2.05+ Build 150211). Link to this questionnaire was broadcasted via social media (e.g. Facebook) and various forums focused on motorcycling uniting motorcyclists in Poland (e.g. http://www.smgp.info/forum; http://forum.motocyklistow.pl). Due to its elaborated character, the questionnaire could be saved partly filled and respondent could complete it later on. The questions were of a single- and multi-answer type. First group of questions asked about age, sex, weight and height of the respondent as well as about motorcycle characteristics such like model, type, daily and weekly riding time, mileage covered monthly, number of seasons and use of protective clothing. Following questions asked about pain in every part of the spine, its frequency and intensity during and after motorcycle riding. Pain intensity was assessed using modified VAS (visual analog scale) in which the examined subject had to indicate pain intensity between 1 and 10 when 1 is the smallest pain and 10 is the worst imaginable pain (Williams, Morlock, Feltner, 2010). Performed modification based on three-grade categorization of pain: slight (VAS 1-3), medium (VAS 4-6), strong (VAS 7-10).

Frequency of pain occurrence during motorcycle riding was quantified in Likert Scale including 5 questions starting from complete acceptance to complete negation. In this study 1 meant very frequent and 5 very rare (Li, 2013).

\section{Statistical analysis}

Statistical analysis was performed using Statistica 10 (StatSoft Inc.). The Shapiro-Wilk test was used to check the accordance to normal distribution while Chi Square Pearson test was used to evaluate the relationships between qualitative variables. Results were considered statistically significant with $p<0.05$.

\section{Results}

In the study group 1,240 persons (58.4\%) experienced pain in any part of spine during riding the motorcycle. Pain was more often reported by men - 770 (43.9\%) - than women - 114 (30.8\%). 569 (26.8\%) persons declared 
neck pain, 187 persons $(8.8 \%)$ - thoracic pain and 826 persons (38.9\%) - lumbo-sacral pain. Pain intensity in VAS averaged in neck $3.96 \pm 0.6,4.19 \pm 1.75$ in thoracic spine, and $4.02 \pm 1.7$ in lumbo-sacral.

Statically significant difference $(p=0.033)$ was stated between pain intensity in spine without division to particular sections and motorcycle type. The highest percentage (51.1\%) of persons with spinal pain was found out in cross/enduro type users. Also statistically significant $(p=0.001)$ difference concerned relationship between neck pain and the use of sport type motorcycle - neck pain occurred in $31.5 \%$ of drivers of this type (Table 3 ).

Table 3. Occurrence of pain in particular parts of spine depending on motorcycle type

\begin{tabular}{lrrrrrrrrr}
\hline \multirow{2}{*}{ Spine segment } & \multicolumn{2}{c}{ Sport } & \multicolumn{2}{c}{ Tourist } & \multicolumn{1}{c}{ Cross/enduro } & \multicolumn{2}{c}{ Chopper/cruiser } & \multirow{2}{*}{$\mathrm{p}$} \\
\cline { 2 - 8 } & \multicolumn{1}{c}{$\mathrm{n}$} & \multicolumn{1}{c}{$\%$} & \multicolumn{1}{c}{$\mathrm{n}$} & \multicolumn{1}{c}{$\mathrm{n}$} & \multicolumn{1}{c}{$\%$} & \multicolumn{1}{c}{$\mathrm{n}$} & \multicolumn{1}{c}{$\%$} & \\
\hline General & 283 & 38.4 & 301 & 42.3 & 72 & 51.1 & 228 & 42.6 & 0.033 \\
Cervical & 232 & 31.5 & 186 & 26.2 & 30 & 21.3 & 121 & 22.6 & 0.001 \\
Thoracic & 76 & 10.3 & 59 & 8.3 & 8 & 5.7 & 44 & 8.2 & 0.234 \\
Lumbo-sacral & 289 & 41.5 & 273 & 40.6 & 47 & 35.6 & 217 & 43.2 & 0.442 \\
\hline
\end{tabular}

No statistically significant difference was stated between motorcycle type and frequency of pain occurrence in any particular spine section (Table 4).

Table 4. Frequency of pain occurrence in particular spine sections depending on motorcycle type

\begin{tabular}{|c|c|c|c|c|c|c|c|c|c|c|}
\hline \multirow[t]{2}{*}{ Motorcycle type } & \multicolumn{2}{|c|}{$\begin{array}{l}\text { Very often } \\
\text { (every day) }\end{array}$} & \multicolumn{2}{|c|}{$\begin{array}{c}\text { Often } \\
\text { (several times } \\
\text { per week) }\end{array}$} & \multicolumn{2}{|c|}{$\begin{array}{l}\text { Sometimes } \\
\text { (several times } \\
\text { per month) }\end{array}$} & \multicolumn{2}{|c|}{$\begin{array}{c}\text { Rarely } \\
\text { (several times } \\
\text { per year) }\end{array}$} & \multicolumn{2}{|c|}{$\begin{array}{c}\text { Very rarely } \\
\text { (once per couple } \\
\text { of years) }\end{array}$} \\
\hline & $\mathrm{n}$ & $\%$ & $\mathrm{n}$ & $\%$ & $\mathrm{n}$ & $\%$ & $n$ & $\%$ & $n$ & $\%$ \\
\hline \multicolumn{11}{|c|}{ Cervical spine } \\
\hline Sport & 14 & 6.03 & 32 & 13.79 & 83 & 35.78 & 91 & 39.22 & 12 & 5.17 \\
\hline Tourist & 5 & 2.69 & 16 & 8.60 & 75 & 40.32 & 79 & 42.47 & 11 & 5.91 \\
\hline Chooper/cruiser & 5 & 4.13 & 20 & 16.53 & 46 & 38.02 & 44 & 36.36 & 6 & 4.96 \\
\hline Cross/enduro & 3 & 10.00 & 2 & 6.67 & 10 & 33.33 & 13 & 43.33 & 2 & 6.67 \\
\hline \multicolumn{11}{|c|}{$p=0.52$} \\
\hline \multicolumn{11}{|c|}{ Thoracic spine } \\
\hline Sport & 7 & 9.21 & 17 & 22.37 & 26 & 34.21 & 25 & 32.89 & 1 & 1.32 \\
\hline Tourist & 2 & 3.39 & 8 & 13.56 & 30 & 50.85 & 15 & 25.42 & 4 & 6.78 \\
\hline Chooper/cruiser & 0 & 0.00 & 8 & 18.18 & 18 & 40.91 & 14 & 31.82 & 4 & 9.09 \\
\hline Cross/enduro & 2 & 25.00 & 0 & 0.00 & 4 & 50.00 & 2 & 25.00 & 0 & 0.00 \\
\hline \multicolumn{11}{|c|}{$p=0.065$} \\
\hline \multicolumn{11}{|c|}{ Lumbo-sacral spine } \\
\hline Sport & 24 & 8.30 & 42 & 14.53 & 111 & 38.41 & 96 & 33.22 & 16 & 5.54 \\
\hline Tourist & 13 & 4.78 & 28 & 10.29 & 106 & 38.97 & 107 & 39.34 & 18 & 6.62 \\
\hline Chooper/cruiser & 12 & 5.56 & 27 & 12.50 & 79 & 36.57 & 89 & 41.20 & 9 & 4.17 \\
\hline Cross/enduro & 3 & 6.38 & 6 & 12.77 & 16 & 34.04 & 15 & 31.91 & 7 & 14.89 \\
\hline \multicolumn{11}{|c|}{$p=0.19$} \\
\hline
\end{tabular}


Also no statistically significant difference was stated between motorcycle type and pain intensity in any spine section (Table 5).

Table 5. Pain intensity in particular spine sections depending on motorcycle type

\begin{tabular}{|c|c|c|c|c|c|c|}
\hline \multirow{2}{*}{ Pain intensity } & \multicolumn{2}{|c|}{ Slight pain } & \multicolumn{2}{|c|}{ Medium pain } & \multicolumn{2}{|c|}{ Strong pain } \\
\hline & $\mathrm{n}$ & $\%$ & $n$ & $\%$ & $n$ & $\%$ \\
\hline \multicolumn{7}{|c|}{ Cervical spine } \\
\hline Sport & 106 & 45.69 & 119 & 51.29 & 7 & 3.02 \\
\hline Tourist & 87 & 46.77 & 98 & 52.69 & 1 & 0.54 \\
\hline Chopper/cruiser & 50 & 41.32 & 67 & 55.37 & 4 & 3.31 \\
\hline Cross/enduro & 12 & 40.00 & 18 & 60.00 & 0 & 0 \\
\hline \multicolumn{7}{|c|}{$p=0.45$} \\
\hline \multicolumn{7}{|c|}{ Thoracic spine } \\
\hline Sport & 29 & 52.73 & 25 & 45.45 & 1 & 1.82 \\
\hline Tourist & 21 & 63.64 & 12 & 36.36 & 0 & 0 \\
\hline Chopper/cruiser & 23 & 69.70 & 10 & 30.30 & 0 & 0 \\
\hline Cross/enduro & 4 & 66.67 & 2 & 33.33 & 0 & 0 \\
\hline \multicolumn{7}{|c|}{$p=0.71$} \\
\hline \multicolumn{7}{|c|}{ Lumbo-sacral pain } \\
\hline Sport & 124 & 63.27 & 65 & 33.16 & 7 & 3.57 \\
\hline Tourist & 114 & 65.14 & 57 & 32.57 & 4 & 2.29 \\
\hline Chopper/cruiser & 94 & 69.12 & 37 & 27.21 & 5 & 3.68 \\
\hline Cross/enduro & 23 & 71.88 & 9 & 28.13 & 0 & 0 \\
\hline
\end{tabular}

\section{Discussion}

The goal of described study was the assessment of pain occurrence in motorcyclists in relationship to motorcycle type. The pain of any spine section occurred generally in $58.4 \%$ persons of the study group. The most frequent location was lumbo-sacral spine which occurred in $38.9 \%$ of respondents whereas in the cervical and thoracic spine these numbers came to $26.8 \%$ and $8.8 \%$ respectively. These results are in a large extent consistent with those published by other authors. Akinbo, Odebiyi, Osasan (2008) who examined spine pain occurrence in Nigerian motorcyclists stated the percentage of general occurrence as $60 \%$ while the lumbar spine pain - also the most frequent - occurred in $43 \%$ of examined persons. Pain in the cervical and thoracic spine together was stated in $13.7 \%$ persons. Pretty similar results were obtained by Mohd Hafzi, Rohayu, Noor Faradila, Wong (2009) who assessed the occurrence of musculoskeletal disorders in two groups - recreational and professional - of Malesian motorcyclists. They stated $62.8 \%$ of low back pain in the recreational group during last 12 months, however in this study the respondents reported two times bigger percentage of neck pain (50.7\%). Makhsous et al. (2009) say that main factors determining such a high percentage of spinal symptoms are long time kept sitting position and reduction of lumbar lordosis while Lis, Black, Korn, Nordlin (2007) stated that the risk of low back pain occurrence is markedly increased by the combination of whole body vibrations and forced improper sitting position. All these 
factors are combined together during riding the motorcycle which may explain such relatively high percentage of low back pain among motorcyclists.

The authors have not found any published data related to the influence of motorcycle type on the occurrence of musculoskeletal system symptoms in motorcyclists. Our assumption of such relationship was based on the differences between positions taken on different motorcycle types which can effect in various loading level in particular spine parts. Velegapudi, Balasubramanian, Babu, Mangaraju (2010) conducted analysis of two different positions - straightened and leaning forward - on motorcycle on the fatigue level of muscles responsible for posture maintaining and driving the motorcycle. The experiment was performed in two different road conditions: providing large number of road shocks and in heavy traffic requiring intensive maneuvering. Muscle fatigue was measured by superficial electromyography (sEMG). The results elicited that leaning forward position causes smaller fatigue when driver is exposed to large number of road shocks while fatigue caused by motorcycle control is similar for both positions. The SEMG measurements were also confirmed by subjective ratings of the driver. On the basis of these results it can be assumed that leaning forward position provides better absorption of shocks and vibrations. It could entail smaller rate of spinal pain occurrence and/or its intensity in case of motorcycles with leaning forward position and higher occurrence rate and/or pain intensity in case of motorcycles with straightened positions. In our study we do not stated significant differences in frequency and intensity of pain symptoms in particular spine sections however in case of sport type motorcycles which have more leaned position the pain occurrence rate in general was in fact the smallest (38.4\%) - however this difference was insignificant. These rates were higher on chopper/cruiser and cross/ enduro type motorcycles $42.6 \%$ and $51.1 \%$ respectively) which have much more straightened positions, however statistical significance was stated for cross/enduro type only. It can be probably linked, besides the position, to riding specificity mainly involving covering tracks in difficult terrain with high number of road shocks and vibrations, frequent changes of driving direction and also higher activity of muscles responsible for maintaining the balance and controlling the motorcycle. This theory seems to be supported by the analysis performed by Wagrowska-Koski (2007) who also links causes of spinal symptoms in drivers with long time maintained position and dynamic changes of spinal loading caused by acceleration and/or braking albeit she emphasizes that general vibrations markedly increase the risk of symptoms linked with sitting position. Similar findings about long lasting sitting position were stated by Balasubramanian, Jagannath (2014) who assessed local muscle fatigue during motorcycle riding using sEMG and seat pressure distribution by pressure mapping system. The study group consisted of 20 men who drove the motorcycle for one hour through the heavy road traffic. Muscle activity was measured bilaterally in following muscles: extensor carpi radialis, biceps brahii, trapezius, sternocleidomastoideus, lattissimus dorsi and erector spinae. Essential fatigue and decrease of postural muscle activity as well as uneven seat pressure distribution were stated. The authors supposed that local fatigue could be caused by long lasting static position and necessity of maintaining the balance on motorcycle.

In our study statistically significant $(p=0.001)$ neck pain occurred in respondents driving the sport type motorcycle. Due to the lack of comparative studies we can only presume that it is the effect of more leaned position that forces cervical spine extension which causes intensive isometric work of neck extensors thus inducing their overloading and pain as a final result. This assumption could be confirmed by conclusions of Hill, Lewis, Papageorgiu, Dziedzic, Croft (2004) who identified riding a bicycle as one of risk factors for neck pain considering the position on bicycle and overloading of neck extensors as the main reasons of pain symptoms. Villavicencio, Hernández, Burneikiene, Thramann (2007) present similar opinion assessing neck pain occurrence in the group of 
triathlonists. They also state the positive relationship between number of hours spent on bicycle and neck symptoms in examined athletes. Taking into consideration the similarity of neck positions on bicycle and on the motorcycle the assumption about use of the sport type motorcycle as a risk factor for neck pain seems to be quite reasonable.

\section{Conclusions}

1. The motorcycle type significantly influences on spinal pain occurrence in general which was the highest in enduro/cross type drivers.

2. The motorcycle type significantly influences on occurrence of neck pain to which the most susceptible are sport type motorcycles drivers.

3. The use of particular motorcycle types do not determine neither the frequency nor the intensity of pain in any spine region.

\section{References}

Akinbo, S.R., Odebiyi, D.O., Osasan, A.A. (2008). Characteristics of back pain among commercial drivers and motorcyclists in Lagos, Nigeria. West African journal of medicine, 2 (27), 87-91.

Balagué, F., Mannion, A. F., Pellisé, F., Cedraschi, C. (2012). Non-specific low back pain. The Lancet, 379 (9814), 482-491. DOI: $10.1016 / \mathrm{S} 0140-6736(11) 60610-7$.

Balasubramanian, V., Jagannath, M. (2014). Detecting motorcycle rider local physical fatigue and discomfort using surface electromyography and seat interface pressure. Transportation research part F: traffic psychology and behavior, 22, 150-158. DOI: 10.1016/j.trf.2013.12.010.

Bovenzi, M. (2010). A longitudinal study of low back pain and daily vibration exposure in professional drivers. Industrial health, 5 (48), 584-595.

Goode, A.P., Carey, T.S., Jordan, J.M. (2013). Low back pain and lumbar spine osteoarthritis: how are they related? Current rheumatology reports, 15 (2), 305. DOI: 10.1007/s11926-012-0305-z.

GUS (2014). Mały Rocznik Statystyczny. Warszawa.

Hill, J., Lewis, M., Papageorgiou, A.C., Dziedzic, K., Croft, P. (2004). Predicting persistent neck pain: a 1-year follow-up of a population cohort. Spine, 15 (29), 1648-1654. DOI: 10.1097/01.BRS.0000132307.06321.3C.

Hoy, D.G., Protani, M., De, R., Buchbinder, R. (2010). The epidemiology of neck pain. Best Practice \& Research Clinical Rheumatology, 6 (24), 783-792. DOI: 10.1016/j.berh.2011.01.019.

Li, Q. (2013). A novel Likert scale based on fuzzy sets theory. Expert Systems with Applications, 5 (40), 1609-1618.

Lis, A.M., Black, K.M., Korn, H., Nordin, M. (2007). Association between sitting and occupational LBP. European Spine Journal, 2 (16), 283-298. DOI: 10.1007/s00586-006-0143-7.

Makhsous, M., Lin, F., Bankard, J., Hendrix, R.W., Hepler, M., Press, J. (2009). Biomechanical effects of sitting with adjustable ischial and lumbar support on occupational low back pain: evaluation of sitting load and back muscle activity. BMC musculoskeletal disorders, 1 (10), 17. DOI: 10.1186/1471-2474-10-17.

Mohd Hafzi, M.I., Rohayu, S., Noor Faradila, P., Wong, S.V. (2009). Prevalence and risk factors of musculoskeletal disorders of motorcyclists. Malaysian Journal of Ergonomics, 1, 1-10.

Sasin, P., Cieślak, W. (2014). Bezpieczeństwo pracy kierowców w transporcie drogowym - ryzyko zawodowe. Przegląd NaukowoMetodyczny „Edukacja dla Bezpieczeństwa”, 1 (7), 111-126.

Sheeran, L., Sparkes, V., Caterson, B., Busse-Morris, M., van Deursen, R. (2012). Spinal position sense and trunk muscle activity during sitting and standing in nonspecific chronic low back pain: classification analysis. Spine, 37 (8), E486-E495. DOI: 10.1097/ BRS.0b013e31823b00ce.

Slatkovska, L., Alibhai, S.M.H., Beyene, J., Cheung, A.M. (2010). Effect of whole-body vibration on BMD: a systematic review and metaanalysis. Osteoporosis international, 12 (21), 1969-1980. DOI: 10.1007/s00198-010-1228-z.

Teoh, E.R., Campbell, M. (2010). Role of motorcycle type in fatal motorcycle crashes. Journal of safety research, 6 (41), 507-512. DOI: 10.1016/j.jsr.2010.10.005 
Williams, V.S., Morlock, R.J., Feltner, D. (2010). Psychometric evaluation of a visual analog scale for the assessment of anxiety. Health and quality of life outcomes, 1 (8), 57. DOI: 10.1186/1477-7525-8-57.

Wagrowska-Koski, E. (ed.) (2007). Zagrożenia zdrowia kierowców pojazdów silnikowych związane ze szkodliwymi i uciążliwymi warunkami środowiska pracy. Instytut Medycyny Pracy im. prof. J. Nofera.

Velagapudi, S.P., Balasubramanian, V., Babu, R., Mangaraju, V. (2010). Muscle fatigue due to motorcycle riding (No. 2010-32-0100). SAE Technical Paper. DOI:10.4271/2010-32-0100.

Villavicencio, A.T., Hernández, T.D., Burneikiene, S., Thramann, J. (2007). Neck pain in multisport athletes. J. Neurosurg: Spine, 7 , 408-413. DOI: 10.3171/SPI-07/10/408.

Cite this article aS: Wójcik, R., Trybulec, B. (2017). Occurrence and Intensity of Spinal Pain in Motorcyclists Depending on Motorcycle Type. Central European Journal of Sport Sciences and Medicine, 4 (20), 81-91. DOI: 10.18276/cej.2017.4-09. 